\title{
Alternanthera bicolor Produces Hypoglycemic Effect in Alloxan-Induced Diabetic Mice through its Antioxidant Activity
}

\author{
Kousik Ahmed Khan ${ }^{1}$, Manik Zahan ${ }^{1}$, Fatema Zohura Talukder ${ }^{1}$, Riaz Uddin ${ }^{1}$, \\ Manik Chandra Shill ${ }^{3}$, Hemayet Hossain ${ }^{2}$, Lutfun Nahar ${ }^{4}$, Satyajit Dey Sarker ${ }^{4}$, \\ Md. Ashraful Alam ${ }^{3}$ and Hasan Mahmud Reza ${ }^{3}$
}

\author{
${ }^{1}$ Department of Pharmacy, Stamford University Bangladesh, 51 Siddeswari Road, Dhaka-1217, Bangladesh \\ ${ }^{2}$ BCSIR Laboratories, Bangladesh Council of Scientific and Industrial Research (BCSIR) \\ Dhaka-1205, Bangladesh \\ ${ }^{3}$ Department of Pharmaceutical Sciences, North South University, Basundhara, Dhaka 1229, Bangladesh \\ ${ }^{4}$ School of Pharmacy and Biomolecular Sciences, Faculty of Sciences, Liverpool John Moores University \\ James Parsons Building, Byrom Street, Liverpool LV3 3AF, England, UK
}

(Received: July 22, 2018; Accepted: February 28, 2019; Published (Web): April 01, 2019)

\begin{abstract}
The current investigation was carried out to evaluate the antioxidant properties of ethanolic extract of Alternanthera bicolor and to assess the potential hypoglycemic effect of the extract in alloxan-induced diabetic mice. HPLC-DAD method was used to determine polyphenolic compounds present in the extract. Different in vitro assays (i.e. DPPH radical scavenging activity test, reducing power test, NO radical inhibition assay and scavenging of hydrogen peroxide) were used to determine the antioxidant potential of the plant. Antidiabetic activity was evaluated in alloxan-induced diabetic mice by glucose tolerance test and standard biochemical analyses. HPLC-DAD analysis of the extract confirmed the presence of (+)-catechin hydrate, caffeic acid, quercetin and kaempferol. A. bicolor showed potent antioxidant activities in DPPH radical, hydrogen peroxide and nitric oxide scavenging assays. Moreover, A. bicolor showed potent reducing power and dose-dependent increment of total antioxidant capacity. Furthermore, the plant showed potent hypoglycemic activities in alloxan-induced diabetic mice. Ethanolic extract of the plant at doses of 200- and 400-mg/kg body weight (administered orally for 3 weeks) significantly decreased the elevated levels of blood glucose, lipid peroxidation product TBARS, hydroperoxides and nitric oxide in experimental animals. Apart from these activities, the ethanolic extract of the plant restored the reduced catalase function in liver. From this study, we can conclude that ethanolic extract of $A$. bicolor exhibited hypoglycemic and antioxidant activities in alloxan-induced diabetic mice.
\end{abstract}

Key words: A. bicolor, lipid peroxidation, caffeic acid, quercetin, diabetes

\section{INTRODUCTION}

Diabetes is a metabolic disorder where pancreatic beta cells are not capable of producing enough insulin to normalize elevated blood glucose levels or muscle tissues are not capable of utilizing circulating blood glucose due to insulin resistance. In recent days, diabetes and insulin resistance are increasing alarmingly both in developed and developing countries. ${ }^{1,2}$ Synthetic drugs such as

Correspondence to: Hasan Mahmud Reza

E-mail: hasan.reza@northsouth.edu

Dhaka Univ. J. Pharm. Sci. 18(1): 49-60, 2019 (June) DOI: https://doi.org/10.3329/dujps.v18i1.41431 metformin, glipizide, gliclazide as well as synthetic insulin itself, are used for the treatment of diabetes. Mostly, these drugs either work as insulin secretagogue (glipizide and glyclazide) or they increase the peripheral insulin uptake (metformin). However, diabetes complications in different tissues arise due to increased oxidative stress and free radical damage. $^{3} \quad$ Increased circulating glucose also overwhelms the mitochondrial respiratory chain and favors more reactive oxygen species (ROS) generation. ${ }^{4}$ Recent evidence suggests that ROS can change insulin receptor and develop insulin 
resistance. ${ }^{3,5}$ Thus, antioxidant supplementation could be a better way of ameliorating oxidative stress in diabetes. Plants are rich sources of natural antioxidants like phenolic acids, flavonoids, anthocyanines, vitamin $\mathrm{C}$ and E. Phenolic acids, anthocyanines, and flavonoids are important classes of antioxidants which also possess anti-diabetic and anti-inflammatory properties. ${ }^{6,7}$ While traditionally many medicinal plants have long been used to heal certain diseases (i.e. hypertension and neurological disorders, and conditions involving pain and inflammation), they have also been used successfully for the treatment of diabetes and insulin resistance. ${ }^{8,9}$

Amarantheceae is a rich plant family that contains more than 700 species. Plants belong to Alternanthera genus of Amarantheceae family have been found to show valuable biological effects such as antioxidants ${ }^{10}$, anti-diabetic ${ }^{11}$, anti-microbial, wound healing ${ }^{12}$, anti-inflammatory ${ }^{13}$ and antinociceptive properties. ${ }^{14} A$. brasiliana is used against inflammation, cough, and diarrhea in Brazilian folk medicine. ${ }^{10}$ Alternanthera genus is also rich source of antioxidant compounds. A. paronychioides prevented ROS-mediated apopotosis in $\beta$-cells due to glucotoxicity. ${ }^{15}$ Previous report also suggests that $A$. brasillian extract possesses antioxidant activity and contains a mixture of $\beta$-sitosterol, stigmasterol and spinasterol. ${ }^{10}$ However, no report is available till to date, on the presence of phenolic compounds in $A$. bicolor. Previously, we reported that Achyranthes aspera from Amarantheceae has hypoglycemic activity due to potent antioxidant activity of the isolated extract against alloxan-induced diabetes in mice. ${ }^{9}$ This study reports hypoglycemic activity of $A$. bicolor extract in alloxan-induced diabetic mice, the antioxidant activity and the presence of phenolic compounds in the extract confirmed by HPLC-DAD system.

\section{MATERIALS AND METHODS}

Chemicals and reagents. Gallic acid (GA), (+)catechin hydrate $(\mathrm{CH})$, vanillic acid (VA), caffeic acid (CA), (-)-epicatechin (EC), p-coumaric acid (PCA), rutin hydrate (RH), ellagic acid (EA), myricetin (MC), kaempferol (KF), and quercetin (QU) were purchased from Sigma-Aldrich (St. Louis, MO, USA). Acetonitrile (HPLC), methanol (HPLC), acetic acid (HPLC), and ethanol was obtained from Merck Inc. (Darmstadt, Germany). Alloxan, 2,2-diphenyl-1-picrylhydrazyl (DPPH), naphthyl ethylene diaminedihydrochloride, FolinCiocalteu reagent, and thiobarbituric acid were also purchased from Sigma-Aldrich, St. Louis, MO, USA. All other reagents were of standard laboratory grade.

Plant material. A. bicolor was collected from the campus of Stamford University Bangladesh, Siddeswari, Dhaka in July 2012 and identified by the experts of the Bangladesh National Herbarium, Mirpur, Dhaka, Bangladesh. Accession number DSCB-32001 was retained there for further references and the specimen was kept in the Phytochemistry and Pharmacology Laboratory, Stamford University Bangladesh.

Extraction process. The dried powder of stem and leaves ( $200 \mathrm{~g})$ was extracted with $80 \%$ of ethanol in a Soxhlet apparatus at an elevated temperature $\left(45 \pm 2^{\circ} \mathrm{C}\right)$. The extract was concentrated by evaporation under reduced pressure at $40^{\circ} \mathrm{C}$ using Buchi rotary evaporator to have gummy concentrate of reddish color extract (\% yield 4.03 ).

Assay for total phenolic content. The concentration of total phenols in extract was measured by UV-Vis spectrophotometer based on a colorimetric oxidation/reduction reaction. ${ }^{16}$ The oxidizing reagent used was Folin-Ciocalteu reagent. Gallic acid was used as standard. Then, $2.5 \mathrm{ml}$ of Folin-Ciocalteu reagent (diluted 10 times with water) and $2 \mathrm{ml}$ of $\mathrm{Na}_{2} \mathrm{CO}_{3}(75 \mathrm{~g} / \mathrm{l})$ were added to $0.5 \mathrm{ml}$ of diluted extract (1 $\mathrm{mg}$ in $4 \mathrm{ml}$ distilled water). The sample was incubated for $20 \mathrm{~min}$ at room temperature. For control sample, $0.5 \mathrm{ml}$ distilled water was used. The absorbance was measured at 760 $\mathrm{nm}$. These data were used to estimate the phenolic content using a standard curve obtained from various concentration of gallic acid.

High performance liquid chromatography (HPLC). Chromatographic analyses were carried out on a Thermo Scientific DionexUltiMate 3000 Rapid 
Separation LC (RSLC) systems (Thermo Fisher Scientific Inc., MA, USA), coupled to a quaternary rapid separation pump (LPG-3400RS), Ultimate 3000RS autosampler (WPS-3000) and rapid separation diode array detector (DAD-3000RS). Phenolic compounds were separated on an Acclaim ${ }^{\circledR}$ $\mathrm{C}_{18}(4.6 \times 250 \mathrm{~mm} ; 5 \mu \mathrm{m})$ column (Dionix, USA) which was maintained at $30^{\circ} \mathrm{C}$ using a temperaturecontrolled column compartment (TCC-3000). Data acquisition, peak integration, and calibrations were performed with DionixChromeleon software (Version 6.80 RS 10).

Details of chromatographic condition, standard polyphenolic compounds and sample solution preparation, peak characterization and quantification of polyphenols have previously been described. ${ }^{17}$

\section{In vitro antioxidant activity test}

DPPH radical scavenging activity. The free radical scavenging capacity of the extract was determined using DPPH. ${ }^{18}$ DPPH solution $(0.004 \%$ w/v) was prepared in $95 \%$ ethanol. Ethanol extract of A. bicolor was mixed with ethanol to prepare the stock solution $(5 \mathrm{mg} / \mathrm{ml})$. Freshly prepared DPPH solution $(0.004 \% \mathrm{w} / \mathrm{v})$ was taken in test tubes. Then, the extract was added followed by serial dilutions ( 1 $\mu \mathrm{g}$ to $500 \mu \mathrm{g}$ ) in every test tube so that the final volume was $3 \mathrm{ml}$ and after $10 \mathrm{~min}$, the absorbance was read at $515 \mathrm{~nm}$ using a spectrophotometer (HACH 4000 DU UV - visible spectrophotometer). Ascorbic acid was used as a reference standard and dissolved in distilled water to make the stock solution with the same concentration $(5 \mathrm{mg} / \mathrm{ml})$. While control sample was prepared containing the same volume without any extract and reference ascorbic acid, 95\% ethanol was used as blank. Percentage of scavenging of the DPPH free radical was measured by using the following equation:

$\%$ Scavenging activity $=$

Absorbance of the control - Absorbance of the test sample Absorbance of the control

Inhibition curve was plotted for duplicate experiments and represented as $\%$ of mean inhibition \pm standard deviation.
Reducing power. The reducing power of $A$. bicolor was examined as previously described. ${ }^{19}$ Different concentrations of the plant extract (100 to $1000 \mu \mathrm{g}$ ) in $1 \mathrm{ml}$ of distilled water were mixed with phosphate buffer $(2.5 \mathrm{ml}, 0.2 \mathrm{M}, \mathrm{pH}$ 6.6) and potassium ferricyanide $\left[\mathrm{K}_{3} \mathrm{Fe}(\mathrm{CN})_{6}\right](2.5 \mathrm{ml}, 1 \%)$. The mixture was incubated at $50^{\circ} \mathrm{C}$ for $20 \mathrm{~min}$. After adding $2.5 \mathrm{ml}$ of trichloroacetic acid (10\%) to the mixture, the resulting final mixture was centrifuged at $3000 \mathrm{rpm}$ for $10 \mathrm{~min}$. The upper layer of the solution $(2.5 \mathrm{ml})$ was mixed with distilled water $(2.5$ $\mathrm{ml})$ and $\mathrm{FeCl}_{3}(0.5 \mathrm{ml}, 0.1 \%)$ and the absorbance was measured at $700 \mathrm{~nm}$. Increased absorbance of the reaction mixture indicated increased reducing power. Ascorbic acid was used as the standard and phosphate buffer ( $\mathrm{pH}$ 6.6) served as blank solution. The absorbance of the final reaction mixture of two parallel experiments was taken and expressed as mean \pm standard deviation.

Nitric oxide (NO) radical inhibition assay. Nitric oxide radical inhibition can be estimated using Griess-Illosvoy reaction. ${ }^{18}$ In this investigation, Griess-Illosvoy reagent was modified by using naphthyl ethylene diaminedihydrochloride $(0.1 \%$ $\mathrm{w} / \mathrm{v})$ instead of 1-napthylamine $(5 \%)$. The reaction mixture $(3 \mathrm{ml})$ containing sodium nitroprusside (10 $\mathrm{mM}, 2 \mathrm{ml})$, phosphate buffer $(0.5 \mathrm{ml})$ and A. bicolor extract (10 to $320 \mu \mathrm{g}$ ) or standard solution (ascorbic acid, $0.5 \mathrm{ml}$ ) was incubated at $25^{\circ} \mathrm{C}$ for $150 \mathrm{~min}$. After incubation, $0.5 \mathrm{ml}$ of the reaction mixture was mixed with $1 \mathrm{ml}$ of sulfanilic acid reagent $(0.33 \%$ in $20 \%$ glacial acetic acid) and allowed to stand for 5 min for completing diazotization. Then, $1 \mathrm{ml}$ of naphthyl ethylene diaminedihydrochloride was added, mixed and allowed to stand for $30 \mathrm{~min}$ at $25^{\circ} \mathrm{C}$. A pink colored chromophore was formed in diffused light. The absorbance of these solutions was measured at $540 \mathrm{~nm}$ against the corresponding blank solutions

Scavenging of hydrogen peroxide. The ability of the extracts to scavenge hydrogen peroxide was determined by the method as previously described. ${ }^{20}$ Hydrogen peroxide (43 $\mathrm{mM})$ was prepared in phosphate-buffered saline (pH 7.4). Standard 
(ascorbic acid) and extract solutions were prepared at concentrations of 50 to $250 \mathrm{mM}$. Aliquots of standard or extract solutions $(3.4 \mathrm{ml})$ were added to $0.6 \mathrm{ml}$ of hydrogen peroxide solution. The reaction mixture was incubated at room temperature for $10 \mathrm{~min}$, and the absorbance was determined at $230 \mathrm{~nm}$. The percentage of scavenging was calculated as follows:

$\% \mathrm{H}_{2} \mathrm{O}_{2}$ scavenging $=$

Absorbance of control - Absorbance of test sample

Absorbance of control

\section{Hypoglycemic activity assay in alloxan-induced diabetic mice}

Animals. Male Swiss albino mice, 3-4 weeks of age, weighing between 20-30 g were used for in vivo pharmacological screening. The mice were collected from the Animal Research Branch of the International Center for Diarrheal Disease and Research, Bangladesh (icddr, b). They were housed in five groups in stainless steel cages $(28 \times 22 \times 13$ inch). Soft wood shavings were used as bedding of cages. The newly collected mice were acclimatized to the new environment for one week prior to the investigation and were maintained at constant room temperature $\left(24.0 \pm 1.0^{\circ} \mathrm{C}\right)$, humidity $55-65 \%$ and 12 hr light/12 hrs dark cycles. Husk and excreta were removed from the cages every day. Food pellets provided by icddr, $b$ were given to the mice with fresh water ad libitum. The institutional animal research ethical committee approved the study protocol.

Experimental design for alloxan-induced diabetes model. A total of 25 mice (20 diabetic surviving mice, 5 normal mice) were used in the experiment.

Group I: Normal mice.

Group II: Diabetic control mice (Alloxan, 150 $\mathrm{mg} / \mathrm{kg}$, intra-peritoneally in citrate buffer $\mathrm{pH} 4.4$ ).

Group II: Diabetic mice given metformin (600 $\mu \mathrm{g} / \mathrm{kg}$ body weight/ day for 3 weeks) in aqueous solution administered using an intarperitoneal route. ${ }^{9}$
Group IV: Diabetic mice given A. bicolor extract ( $200 \mathrm{mg} / \mathrm{kg}$ body weight/day for 3 weeks) in aqueous solution administered via an intragastric tube.

Group V: Diabetic mice given A. bicolor (400 $\mathrm{mg} / \mathrm{kg}$ body weight/ day for 3 weeks) in aqueous solution administered via an intragastric tube.

The diabetic condition was assessed by determining the blood glucose concentration at 3 and 5 days after alloxan treatment. No detectable irritation or restlessness was observed after each drug or vehicle administration. No noticeable adverse effects (i.e. respiratory distress, abnormal locomotion and catalepsy) were observed in any animals after the drug administration.

Glucose tolerance test. Animals were fasted overnight and divided into 5 groups of 5 mice. Control animals were given $1 \mathrm{ml}$ of distilled water orally (Group I). Group II and III were diabetic control group (alloxan, $150 \mathrm{mg} / \mathrm{kg}$, intra-peritoneally in citrate buffer $\mathrm{pH} 4.4)$ and diabetic mice given metformin $(600 \mu \mathrm{g} / \mathrm{kg}$ body weight/ day for 3 weeks $)$ in aqueous solution administered via intarperitoneal route, respectively. A. bicolor extract was administered orally using a feeding syringe at concentrations of 200 and $400 \mathrm{mg} / \mathrm{kg}$ to Group IV and $\mathrm{V}$, respectively). All groups were given glucose $(2 \mathrm{~g} / \mathrm{kg})$ orally. Blood samples were collected from the tail vein just prior to and 60, 120 and $180 \mathrm{~min}$ after glucose administration. Blood glucose concentrations were assayed by a glucometer. Results achieved from glucose tolerance test were taken as a hypothetical reference to extrapolate the dose levels which will be used for evaluation of short- and longterm effects of A. bicolor extract on diabetes in mice.

Blood samples collection. Blood samples were collected from fasting animal at weekly intervals till the end of study from tail tip of each mouse and used for the assay of glucose level in plasma. At the end of the $3^{\text {rd }}$ week, all the mice were sacrificed by highdose anesthesia (Pentobarbitone sodium, $60 \mathrm{mg} / \mathrm{kg}$ ).

Liver sample collection. Liver was immediately dissected and washed in ice cold saline to remove the blood. Livers were weighed and $10 \%$ tissue homogenate was prepared with $0.025 \mathrm{M}$ Tris $-\mathrm{HCl}$ 
buffer at $\mathrm{pH}$ 7.5. After centrifugation at $2000 \mathrm{rpm}$ for $10 \mathrm{~min}$, the clear supernatant was collected and used to measure thiobarbituric acid reactive substances (TBARS), hydroperoxides, NO level and catalase activity.

\section{Biochemical analyses}

Estimation of blood glucose. Glucose level was measured in serum of non-fasting of mice. Blood was sampled from tail tip and thereafter, analyzed with a glucometer using commercial strips (OneTouch Ultra glucose test strip).

Estimation of lipid peroxidation. Lipid peroxidation in liver was estimated colorimetrically by measuring thiobarbituric acid reactive substances (TBARS) as as previously described. ${ }^{21}$ In brief, 0.1 $\mathrm{ml}$ of tissue homogenate (Tris- $\mathrm{HCl}$ buffer, $\mathrm{pH}$ 7.5) was treated with $2 \mathrm{ml}$ of TBA:TCA: $\mathrm{HCl}$ mixture (1:1:1 ratio) (thiobarbituric acid $0.37 \%, 0.25 \mathrm{~N} \mathrm{HCl}$ and $15 \% \mathrm{TCA}$ ) and placed in water bath for $15 \mathrm{~min}$ and then, cooled to room temperature. The absorbance of clear supernatant was measured against reference blank at $535 \mathrm{~nm}$.

Estimation of hydroperoxidase. Hydroperoxidase level was estimated by the method described before. ${ }^{22}$ Here, $0.1 \mathrm{ml}$ of tissue homogenate treated with $0.9 \mathrm{ml}$ of Fox reagent $(88 \mathrm{mg}$ butylatedhydroxytoluene, BHT; $7.6 \mathrm{mg}$ xylenol orange and $9.8 \mathrm{mg}$ ammonium iron sulphate) was added to $90 \mathrm{ml}$ of methanol and $10 \mathrm{ml}$ of 250 mMsulphuric acid and was incubated at $37^{\circ} \mathrm{C}$ for 30 min. The developed color was read at $560 \mathrm{~nm}$ colorimetrically. Hydroperoxidase was expressed as $\mathrm{mM} / 100 \mathrm{~g}$ tissue.

Assay of catalase (CAT). CAT was assayed colorimetrically at $620 \mathrm{~nm}$ and expressed as $\mu$ moles of $\mathrm{H}_{2} \mathrm{O}_{2}$ consumed $/ \mathrm{min} / \mathrm{mg}$ protein as described by Sinha. ${ }^{23}$ The reaction mixture $(1.5 \mathrm{ml})$ contained 1.0 $\mathrm{ml}$ of $0.01 \mathrm{M}$ at $\mathrm{pH} 7.0$ phosphate buffer, $0.1 \mathrm{ml}$ of tissue homogenate (supernatant) and $0.4 \mathrm{ml}$ of $2 \mathrm{M}$ $\mathrm{H}_{2} \mathrm{O}_{2}$. The reaction was stopped by addition of $2.0 \mathrm{ml}$ of dichromate-acetic acid reagent $(5 \%$ potassium dichromate and glacial acetic acid were mixed at 1:3 ratio).
Assay of NO. NO was determined according to the method described by Tracy et al. as nitrate and nitrite. ${ }^{24}$ In this study, Griess-Illosvoy reagent was modified by using naphthyl ethylene diaminedihydrochloride $(0.1 \% \mathrm{w} / \mathrm{v})$ instead of 1 napthylamine $(5 \%)$. The reaction mixture $(3 \mathrm{ml})$ containing brain homogenates $(2 \mathrm{ml})$ and phosphate buffer saline $(0.5 \mathrm{ml})$ was incubated at $25^{\circ} \mathrm{C}$ for 150 min. The rest of process was followed as described in previous experiment of NO scavenging assay of the extract. A pink colored chromophore was formed in diffused light. The absorbance of these solutions was measured at $540 \mathrm{~nm}$ against the corresponding blank solutions. NO level was measure using standard curve and expressed as nmol/g of tissue.

Statistical analysis. All data are presented as mean \pm standard error of mean (SEM) or mean \pm standard deviation (SD). One way analysis of variance (ANOVA) followed by Newman-Keuls Post-hoc test was done for statistical comparison among groups using Graph Pad Prism Software (USA). A p $<0.05$ was considered to be statistically significant. $\mathrm{IC}_{50}$ values for scavenging of free radicals by the extracts were also calculated from doseresponse curve using default analyzing tab of Graph Pad Prism Software (USA).

\section{RESULTS AND DISCUSSION}

Phytochemical screening. Preliminary phytochemical screening of the extract showed the presence of flavonoids, tannins, gum, reducing sugar and saponins (Table 1).

Table 1. Phytochemical screening of $\boldsymbol{A}$. bicolor extract.

\begin{tabular}{lc}
\hline Test & A. bicolor \\
\hline Alkaloids & - \\
Flavonoids & + \\
Tannins & ++ \\
Gum & + \\
Reducing sugar & ++ \\
Saponins & + \\
\hline
\end{tabular}

Total phenolic content. The amount of total phenolic content was found in high amount in the 
ethanolic extract of A. bicolor $(267.89 \pm 10.97 \mathrm{mg} / \mathrm{g}$ of gallic acid equivalent) (Table 2).

\section{Antioxidant activity}

DPPH radical scavenging activity. The ethanolic extract of A. bicolor exhibited a significant dose-dependent inhibition of DPPH radical scavenging activity (Figure 1a), with a $50 \%$ inhibition $\left(\mathrm{IC}_{50}\right)$ at a concentration of $52.02 \pm 3.37$ $\mu \mathrm{g} / \mathrm{ml}$ while the $\mathrm{IC}_{50}$ value of the standard ascorbic acid was found to be $16.04 \pm 0.04 \mu \mathrm{g} / \mathrm{ml}$ (Table 2).

Table 2. Effect of A. bicolor extract on scavenging of free radicals in various in vitro systems.

\begin{tabular}{lcc}
\hline \multirow{2}{*}{ Antioxidant assays } & \multicolumn{2}{c}{$\mathrm{IC}_{50}$ values $(\mu \mathrm{g} / \mathrm{ml})$} \\
\cline { 2 - 3 } & $\begin{array}{c}\text { Ascorbic } \\
\text { acid }\end{array}$ & A. bicolor \\
\hline $\begin{array}{l}\text { DPPH radical } \\
\text { scavenging assay }\end{array}$ & $16.04 \pm 0.04$ & $52.02 \pm 3.37^{* *}$ \\
$\begin{array}{l}\text { NO radical } \\
\text { scavenging assay }\end{array}$ & $19.85 \pm 1.03$ & $10.76 \pm 0.06^{* *}$ \\
$\begin{array}{l}\mathrm{H}_{2} \mathrm{O}_{2} \text { radical } \\
\text { scavenging assay } \\
\text { Total phenolic content }\end{array}$ & $42.67 \pm 2.92$ & $140.05 \pm 7.28^{* *}$ \\
& - & $\begin{array}{c}267.89 \pm 10.97 \\
\text { (mg of gallic acid } \\
\text { equivalent (GAE) }\end{array}$ \\
& & per g of dry extract) \\
\hline
\end{tabular}

Data are presented as mean $\pm \mathrm{SD}, \mathrm{n}=2$. Statistical analysis was conducted as paired student ' $\mathrm{t}$ ' test. Values are considered significant at $p<0.05$ between the control and the sample.

Nitric oxide radical inhibition assay. The scavenging of NO by plant extract was increased in a dose-dependent manner as illustrated in figure $1 \mathrm{~b}$. At the concentration of $10.76 \pm 0.06 \mu \mathrm{g} / \mathrm{ml}$ of extract, $50 \%$ of nitric oxide generated by incubation was scavenged (Table 2). This $\mathrm{IC}_{50}$ value of the extract was found to be similarly effective as standard vitamin $\mathrm{C}\left(\mathrm{IC}_{50} 19.85 \pm 1.03 \mu \mathrm{g} / \mathrm{ml}\right)$.

Hydrogen peroxide scavenging. The scavenging of hydrogen peroxide by the standard (ascorbic acid) and extract after incubation for 10 min, increased with increased concentration (Figure 1c). The crude extract has high electron-donating abilities as $50 \%$ scavenging was achieved at the concentration of crude extract of $42.67 \pm 2.92 \mu \mathrm{g} / \mathrm{ml}$ (Table 2).
In comparison, $50 \%$ scavenging of the hydrogen peroxide was achieved at $140.05 \pm 7.28 \mu \mathrm{g} / \mathrm{ml}$ of ascorbic acid.

Reducing power and total antioxidant capacity. Figure 1d shows the reducing capabilities of the plant extract compared to butylated hydroxy toluene and ascorbic acid. The reducing power of extract of A. bicolor was mild and increased with increasing quantities of the sample. The plant extract could reduce the most of $\mathrm{Fe}^{3+}$ ions which had a lesser reductive activity than the standard butylated hydroxytoluene and ascorbic acid. Moreover, total antioxidant capacity also increased in a concentration-dependent manner which is presented in figure 1e.

HPLC-DAD analysis of phenolic compounds present in $\boldsymbol{A}$. bicolor. Identification and quantification of individual phenolic compounds of A. bicolor ethanolic extract was performed by HPLCDAD system. The chromatographic separations of polyphenols of ethanol extract are shown in figure 2. The results indicate that the extract contains (+)catechin hydrate, caffeic acid, quercetin and kaempferol (Table 3). However, caffeic acid and quercetin seem to be aboundantly present in the extract.

Table 3. Contents of polyphenolic compounds in the ethanol extract of A. bicolor $(n=3)$.

\begin{tabular}{lcc}
\hline \multirow{2}{*}{$\begin{array}{l}\text { Polyphenolic } \\
\text { compound }\end{array}$} & \multicolumn{2}{c}{ Ethanol extract of A. bicolor } \\
\cline { 2 - 3 } & $\begin{array}{c}\text { Content (mg/100 g } \\
\text { of dry extract) }\end{array}$ & $\%$ RSD \\
\hline (+)-Catechin hydrate & 40.18 & 0.68 \\
Caffeic acid & 101.27 & 4.32 \\
Quercetin & 103.52 & 4.81 \\
Kaempferol & 25.74 & 0.95 \\
\hline
\end{tabular}

Antidiabetic activity in alloxan-induced diabetic mice

Oral glucose tolerance test in diabetic and normal mice. The oral glucose tolerance test of nondiabetic mice showed a dose-dependent decrease of glucose in plasma after administration of the extract of the plant over a $3 \mathrm{hrs}$ time period (Figure 3A). Maximum reduction of glucose level of 42.24 and 
$38.02 \%$, for 200 and $400 \mathrm{mg} / \mathrm{kg}$ dose group, respectively was noted in the third hour of the study period. Diabetic control group animals showed increasing concentration of the glucose level throughout the first and second hour of study period and mild alteration was observed which is probably due to glucose homeostasis. a

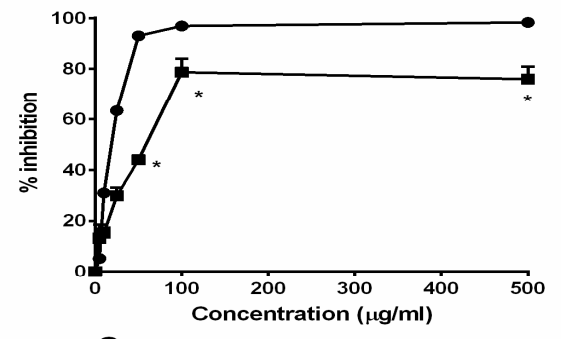

C

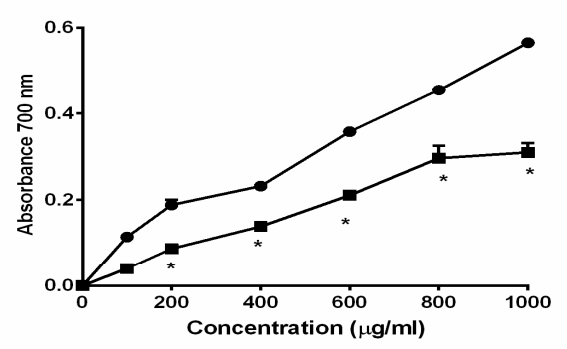

e

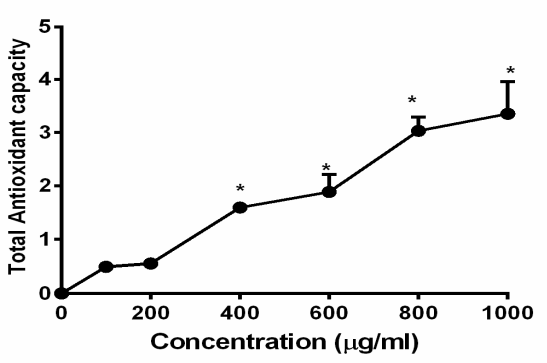

b

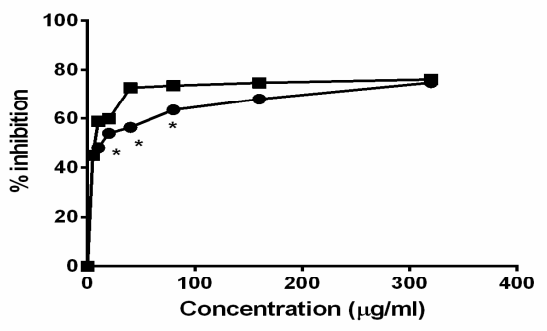

d

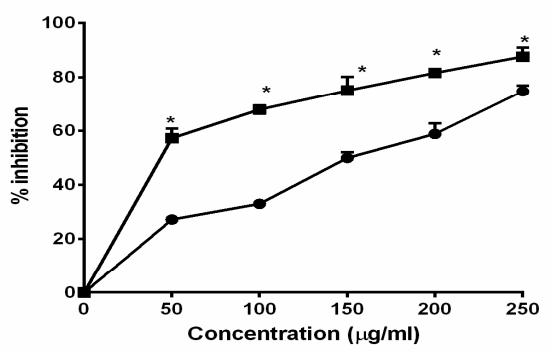

Ascorbic acid

\section{A bicolor}

Figure 1. Effect of Alternanthera bicolor extract assessed by various antioxidant assays. a) Scavenging of DPPH radical by ascorbic acid and extract of A. bicolor, b) Scavenging of $\mathrm{NO}^{-}$radical by ascorbic acid and extract of A. bicolor, c) Scavenging of $\mathrm{H}_{2} \mathrm{O}_{2}$ radical by ascorbic acid and extract of A. bicolor, d) Reducing power of ascorbic acid and extract of A. bicolor, e) Total antioxidant capacity of extract of A. bicolor. Data are presented as mean $\pm \mathrm{SD}, \mathrm{n}=2$. Statistical analysis was conducted as paired student 't' test. Values are considered significant at $\mathrm{p}<0.05$ between the control and the sample.

Effect of $A$. bicolor extract on body weight in alloxan-treated mice. The body weight changes in diabetic group significantly decreased $(\mathrm{p}<0.05)$ when compared with the normal control, which then, returned to near normal level in diabetic mice treated with A. bicolor at 200 and $400 \mathrm{mg} / \mathrm{kg}$ body weight (Figure 3B). Alloxan administration caused a significant weight loss after 3 weeks of treatment from $23.2 \pm 1.48 \mathrm{~g}$ to $21.20 \pm 0.84 \mathrm{~g}$ whereas mice in the normal group continued to gain weight.
Treatment with A. bicolor (200 and $400 \mathrm{mg} / \mathrm{kg}$ ) recovered the weight loss.

Effect of A. bicolor extract on plasma glucose level in alloxan-treated mice. A single intraperitoneal injection of alloxan $(150 \mathrm{mg} / \mathrm{kg}$ body weight) elevated the glucose levels to $>160 \mathrm{mg} / \mathrm{dl}$ after 5 days. The ethanol extract of A. bicolor significantly decreased the blood glucose level. Serum glucose levels in normal mice group (Group I) 
reached steady concentrations of $79.92 \pm 5.34 \mathrm{mg} / \mathrm{dl}$ in the $2^{\text {nd }}$ week and $79.20 \pm 2.20 \mathrm{mg} / \mathrm{dl}$ in the $3^{\text {rd }}$ week, while significant increment was observed ( $p>0.05)$ in the diabetic control group (Group II), $178.20 \pm$ $10.26 \mathrm{mg} / \mathrm{dl}$ and $182.16 \pm 5.46 \mathrm{mg} / \mathrm{dl}$ in the $2^{\text {nd }}$ and $3^{\text {rd }}$ week, respectively as compared to the control group. In the metformin-treated group (Group III) plasma glucose level decreased significantly during the experimental period. The glucose lowering activity of the extract $(200 \mathrm{mg} / \mathrm{kg})$ initiated in the $2^{\text {nd }}$ week with a reduction of $120.96 \pm 13.97 \mathrm{mg} / \mathrm{dl}$ and reached its maximum reduction in the $3^{\text {rd }}$ week by $110.88 \pm 9.32$ $\mathrm{mg} / \mathrm{dl}$. This study also revealed that administration of A. bicolor $(400 \mathrm{mg} / \mathrm{kg})$ reduced the elevated glucose level significantly in the $2^{\text {nd }}$ week after alloxan administration to $115.20 \pm 16.15 \mathrm{mg} / \mathrm{dl}$ and in the $3^{\text {rd }}$ week glucose level further decreased to $106.92 \pm 12.83$ $\mathrm{mg} / \mathrm{dl}$. Thus, A. bicolor showed anti-diabetic effect in a concentration-dependent manner in the $2^{\text {nd }}$ and $3^{\text {rd }}$ week (Figure 4) of treatment and the activity was found similar to that of metformin-treated group at higher dose and found to be statistically significant $(\mathrm{p}<0.05)$.

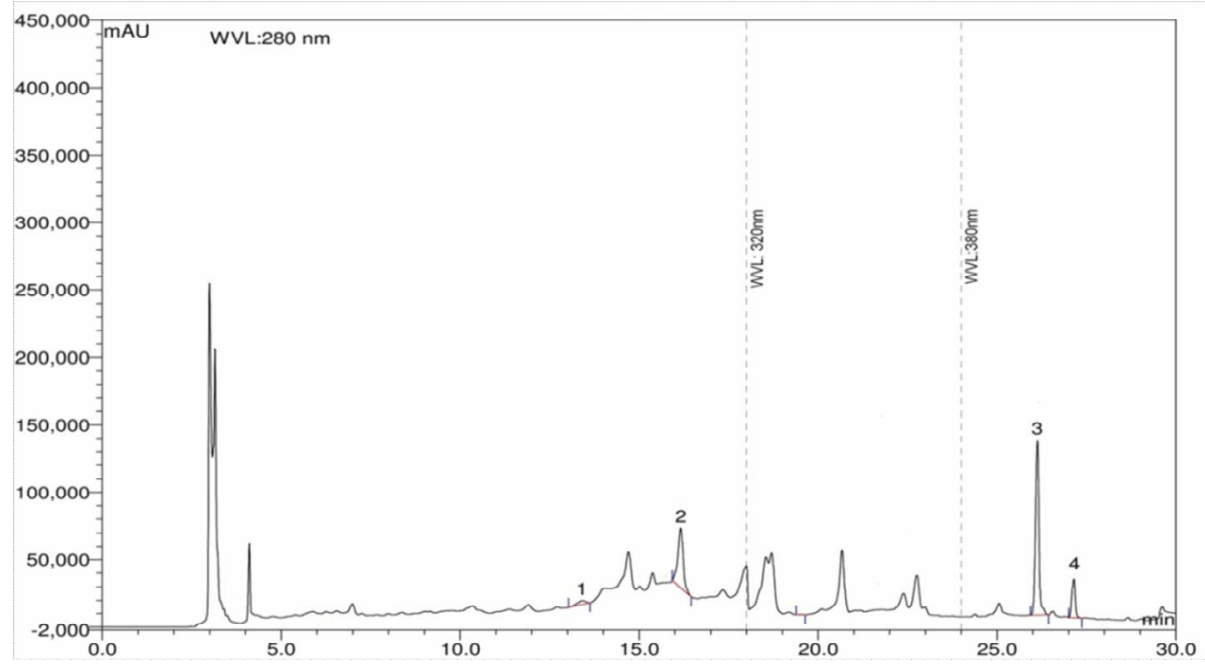

Figure 2. HPLC chromatogram of ethanol extract of A. bicolor. Peaks: 1, (+)-catechin hydrate; 2, caffeic acid; 3, quercetin; 4, kaempferol.
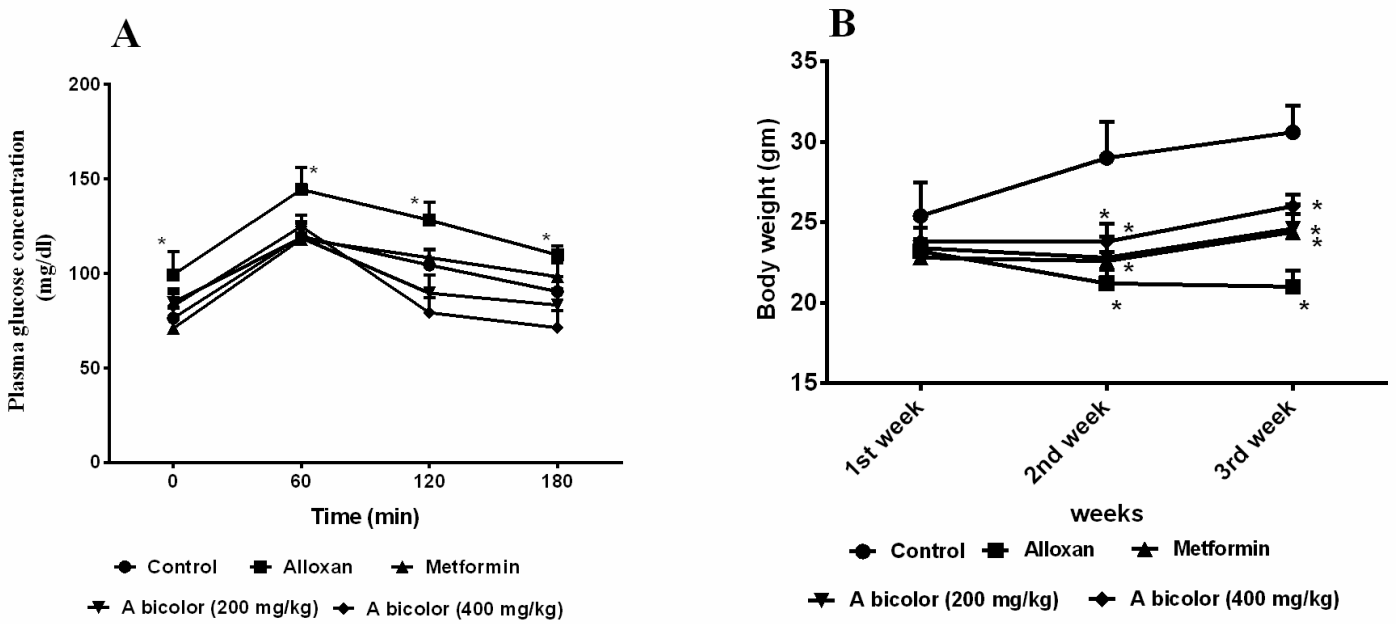

Figure 3. (A) Oral glucose tolerance test (OGTT) and (B) Effect of A. bicolor extract on the body weight in alloxan-induced diabetes in mice. Data are presented as mean \pm SEM, $n=5$. Statistical analysis was conducted as one way ANOVA followed by Newman-Keuls multiple comparison tests. *p $<0.05$ as compared with the control. 


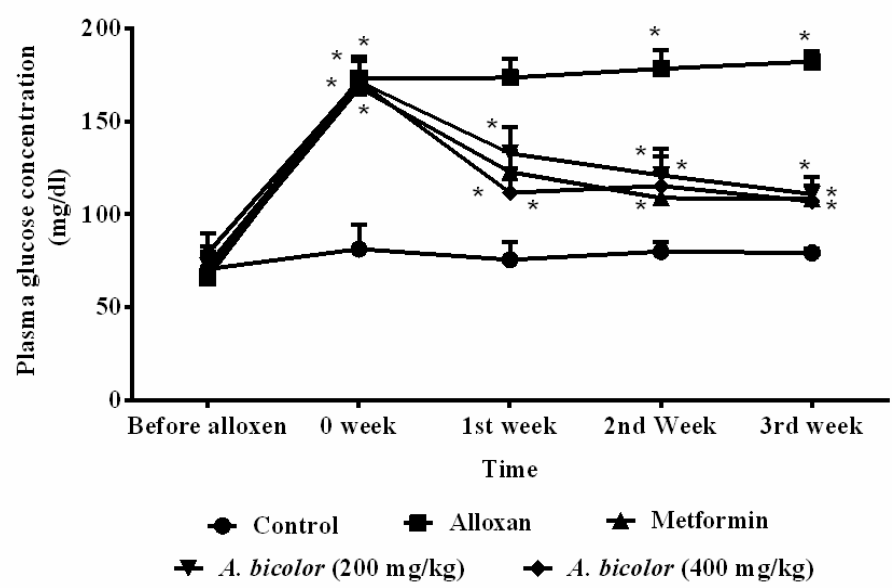

Figure 4. Effect of A. bicolor extracts on plasma glucose concentration in alloxan-induced diabetes in mice. Data are presented as mean \pm $\mathrm{SEM}, \mathrm{n}=5$. Statistical analysis was conducted as one way ANOVA followed by Newman-Keuls multiple comparison tests. *p<0.05 as compared with the control.

Table 4. Effect of Alternanthera bicolor ethanol extract on various parameters in alloxan-induced diabetes in mice.

\begin{tabular}{lcccc}
\hline Groups & MDA $(\mathrm{nmol} / \mathrm{ml})$ & $\begin{array}{c}\text { Hydroperoxides } \\
(\mathrm{nmol} / \mathrm{ml})\end{array}$ & $\begin{array}{c}\text { Nitric oxide level } \\
(\mathrm{nmol} / \mathrm{ml})\end{array}$ & $\begin{array}{c}\text { Catalase } \\
(\mathrm{nmol} / \mathrm{min} / \mathrm{mg})\end{array}$ \\
\hline Control & $14.00 \pm 1.58$ & $15.16 \pm 1.36$ & $14.24 \pm 1.62$ & $41.03 \pm 0.59$ \\
Diabetes control & $41.94 \pm 2.85^{*}$ & $26.88 \pm 2.97 *$ & $29.25 \pm 1.69^{*}$ & $22.80 \pm 2.18^{*}$ \\
Metformin & $27.09 \pm 1.71^{*}$ & $17.64 \pm 1.28^{*}$ & $18.28 \pm 5.53^{*}$ & $31.90 \pm 3.92^{*}$ \\
A. bicolor $(200 \mathrm{mg} / \mathrm{kg})$ & $30.36 \pm 1.77^{*}$ & $19.50 \pm 2.72^{*}$ & $22.75 \pm 2.35^{*}$ & $42.98 \pm 2.55^{*}$ \\
A. bicolor $(400 \mathrm{mg} / \mathrm{kg})$ & $28.03 \pm 2.49^{*}$ & $9.62 \pm 1.16^{*}$ & $21.79 \pm 2.72^{*}$ & $42.93 \pm 2.02^{*}$ \\
\hline
\end{tabular}

Data are presented as mean $\pm \mathrm{SEM}, \mathrm{n}=5$. Data are analyzed by using One way ANOVA followed by Newman-Keuls multiple comparison tests. *p<0.05 as compared with the control.

Effect of $A$. bicolor extract on liver TBARS, catalase, hydroperoxides and nitric oxide (NO) level in alloxan-treated mice. The levels of malondialdehyde (MDA) as a lipid peroxidation product measured as TBARS in liver, significantly $(\mathrm{p}<0.05)$ increased in alloxan-induced diabetic mice as compared to normal mice. Treatment with $A$. bicolor significantly decreased the level of lipid peroxidation products (TBARS). A significant decrease $(\mathrm{p}<0.05)$ in the activities of antioxidant enzymes such as CAT and peroxidase was also observed in the liver of alloxan-induced diabetic mice as compared to that of normal mice. Upon administration of $200-$ and $400-\mathrm{mg} / \mathrm{kg}$ body weight of the plant extract, the activities of both CAT andperoxidase were significantly reversed to near normal. The level of NO significantly increased in liver of alloxan-induced diabetic mice. Treatment with the plant extract significantly decreased the levels of NO in diabetic mice. The results are shown in table 4.

The aim of the present study was to assess antidiabetic and antioxidant potential of $A$. bicolor extract in alloxan-induced diabetic mice. Our investigation found potent antioxidant activity of the plant extract in various in vitro antioxidant assays such as DPPH radical scavenging assay, $\mathrm{H}_{2} \mathrm{O}_{2}$ scavenging assay, NO radical scavenging assay, prevention of lipid peroxidation, etc. Moreover, our results showed that ethanol extract of A. bicolor (200 and $400 \mathrm{mg} / \mathrm{kg}$ of body weight) reduced the blood glucose level and reduced free radical-mediated oxidative stress in alloxan-induced diabetic mice as compared to normal mice.

There is a direct relationship between antioxidant activity and total phenolic content found in the 
medicinal plants. Phenolic compounds present in the plants showed major contribution to antioxidant activity. $^{25,26}$ Our preliminary phytochemical tests suggest the presence of tannins and flavonoids compounds in the extract. Further, we have analyzed the phenolic contents in the extracts by HPLC-DAD system. For the detection of phenolic contents of the extracts, we followed previously described method with some modifications. ${ }^{27}$ Among different separation systems, HPLC analysis includes the use of a binary solvent system containing acidified water and a polar organic solvent was developed to specifically measure polyphenolic concentrations. ${ }^{28,29}$ In this study, we used eleven different phenolic standards, $\mathrm{C}_{18}$ column with $250 \mathrm{~mm}$ length, and rapid separation LC (RSLC) systems while the previously reported method describes the use of six standards, $\mathrm{C}_{18}$ column with $150 \mathrm{~mm}$ length, and HP 1090, series II, liquid chromatography systems to determine the polyphenolic contents. ${ }^{27}$ The wavelength was set between 210 and $380 \mathrm{~nm}$ for detection of polyphenolic compounds. ${ }^{28,30}$ Therefore, 280, 320 and $380 \mathrm{~nm}$ wavelengths were selected for detection of all standards in this study. Our results confirmed the presence of $(+)$-catechin hydrate, caffeic acid, quercetin and kaempferol which are all strong natural antioxidants. In vitro antioxidant assays also showed that A. bicolor extract is strong scavenger of free radicals and/or ROS like DPPH, hydrogen peroxide and nitric oxide. Moreover, A. bicolor extract possesses high amounts of phenolic contents and showed strong reducing capabilities where it probably acts as a source of reductone. Generally, reductones can donate hydrogen atoms to neutralize or break the free radical chains. ${ }^{31}$

Our investigation also showed hypoglycemic activity and inhibits oxidative stress in alloxaninduced diabetic mice. Alloxan-induced diabetes is a well-established chemical-induced diabetic model in laboratory rodents. The diabetic and A. bicolortreated diabetic mice showed a reduction in their body weight. While normal control mice showed increased body weight gain throughout the study, $A$. bicolor-treated mice maintained their body weight during this time. Weight loss in alloxan-treated animals is probably due to the degeneration of adipocytes and muscle tissues. Alloxan acts as selective free radicals for pancreatic beta cell and destroys beta cells using free radical-mediated signal pathways. ${ }^{32}$ As a result, blood glucose level rises dramatically in fasting animals. Thus, it can be used to produce a model which can assess the hypoglycemic activity of new drug candidate(s). In the present study, elevated blood glucose level in alloxan-induced diabetic mice was significantly normalized both in oral glucose tolerance test (OGTT) and in long-term (3-week) study as compared to the normal mice. Previously, it was reported that flavonoids and polyphenols showed potent anti-diabetic activities. ${ }^{33}$ Moreover, it is also documented that plant antioxidants are able to restore and regenerate pancreatic beta cells. ${ }^{32}$ In the current investigation, A. bicolor revealed the presence of various flavonoids, tannins and polyphenolic compounds like (+)-catechin hydrate, caffeic acid, quercetin and kaempferol. In previous studies, caffeic acid and quercetin showed hypoglycemic activity in diabetic animals. ${ }^{34-36}$ Hence, the anti-diabetic activity of A. bicolor is probably due to the presence of several bioactive anti-diabetic principles and their synergistic properties. Similar hypoglycemic activity was also observed by other investigators. ${ }^{37}$

It has been established that diabetes leads to increased production of oxygen free radicals. ${ }^{38}$ Several studies have illustrated the increased lipid peroxidation in clinical and experimental diabetes. ${ }^{39-41}$ A possible mechanism for oxidative stress in diabetes is auto-oxidation of sugar and unsaturated lipid that leads to production of free radicals which are responsible for damages in the end organ. The major organ involved in diabetic complications is liver. Alloxan induces membrane lipid peroxidation and extensive DNA strand breakage. $^{42}$ The increased level of lipid peroxides and TBARS in diabetic mice indicated the degenerative status in diabetes which was significantly reduced by A. bicolor extract. Moreover, pathogenesis of different diabetic complications is originated from oxidative stress which results from an imbalance between the production of free radicals 
and the effectiveness of the antioxidant defense system. ${ }^{40}$ Several lines of defenses such as superoxide dismutase, catalase and peroxidases are present to detoxify the free radicals generated in tissues during diabetes. Catalase presents in almost all aerobic cells to catalyze hydrogen peroxide into molecular oxygen and water without the production of free radicals. In our study, the activity of this enzyme was significantly decreased in the liver of alloxan-induced diabetic animals due to increased oxidative stress. Thus, it is quite logical to assume that these changes were brought back to normal after treatment with $A$. bicolor extract.

Our investigations showed that $A$. bicolor extract possesses potent free radical scavenging activity in several antioxidant assays and contains abundant amount of caffeic acid and quercetin in the extract. Moreover, A. bicolor extract reduced oxidative stress and improved hyperglycemic condition. This beneficial effect is probably partly mediated by reducing elevated blood glucose level and improvement of antioxidant status in diabetic condition. Thus, it can be used as a complementary medicine for the treatment of diabetes. However, further research is warranted to elucidate the mechanisms underlying the protective effect of the extract on liver and pancreas in diabetes.

\section{ACKNOWLEDGEMENT}

Authors gratefully acknowledge the support of Department of Pharmacy, Stamford University Bangladesh for providing us with the laboratory space, reagents and facilities.

\section{Conflict of Interest}

None.

\section{REFERENCES}

1. Ramachandran, A., Snehalatha, C., Shetty, A.S. and Nanditha, A. 2012. Trends in prevalence of diabetes in Asian countries. World J. Diabetes 3, 110-117.

2. Unwin, N., Whiting, D., Gan, D., Jacqmain, O. and Ghyoot, G. 2009. IDF Diabetes Atlas. 4th ed. Brussels: International Diabetes Federation.
3. Giacco, F. and Brownlee, M. 2010. Oxidative stress and diabetic complications. Circulation Res. 107, 1058-1070.

4. Kim, J.A., Wei, Y. and Sowers, J.R. 2008. Role of mitochondrial dysfunction in insulin resistance. Circulation Res. 102, 401-414.

5. Qatanani, M. and Lazar, M.A. 2007. Mechanisms of obesityassociated insulin resistance: many choices on the menu. Genes \& Development 21, 1443-1455.

6. Pandey, K.B. and Rizvi, S.I. 2009. Plant polyphenols as dietary antioxidants in human health and disease. Oxid. Med. Cell Longev. 2, 270-278.

7. Wallace, T.C. 2011. Anthocyanins in cardiovascular disease. Adv. Nutr. 2, 1-7.

8. Day, C., Cartwright, T., Provost. J. and Bailey, C.J. 1990. Hypoglycaemic effect of Momordica charantia extracts. Planta Med. 56, 426-429.

9. Talukder, F.Z., Khan, K.A., Uddin, R., Jahan, N. and Alam, M.A. 2012. In vitro free radical scavenging and antihyperglycemic activities of Achyranthes aspera extract in alloxan-induced diabetic mice. Drug Discov. \& Therapeutics. 6, 298-305.

10. Pereira, D.F., Zanon, R., Santos, M.D., Boligon, A. and Athayde, M. 2013. Antioxidant activities and triterpenoids isolated from Alternanthera brasiliana (L.) Kuntze leaves. Nat. Prod. Res. 27, 1660-1663.

11. Tan, K.K. and Kim, K.H. 2013. Alternanthera sessilis red ethyl acetate fraction exhibits antidiabetic potential on obese Type 2 diabetic rats. Evid. Bare. Compl. Altern. Med. 8.

12. Barua, C.C., Begum, S.A., Talukdar, A., Datta Roy, J., Buragohain. B., Chandra, P.D., Kumar, S.D., Saikia, B.R. and Gupta, A. 2012. Influence of Alternanthera brasiliana (L.) Kuntze on altered antioxidant enzyme profile during cutaneous wound healing in immunocompromised rats. Int. Scholar. Res. Network-Pharmacol.8.

13. Formagio, E., Mendel, M., Fracasso, R., Knobloch, J., Teixeira, P., Kehl, L., Maluf, R., Picoli, S., Ardenghi, P. and Suyenaga, E. 2012. Evaluation of the pharmacological activity of the Alternanthera brasiliana aqueous extract. Pharm. Biol. 50, 1442-1447.

14. Khatun, F., Zaman, F., Mosaiab, T., Mostafa, F., Zaman, M., Rehana, F., Nasrin, D., Jamal, F., Nahar, N. and Rahmatullah, M. 2012. Evaluation of antinociceptive and antihyperglycemic activities in methanol extracts of whole plants of Alternanthera philoxeroides (Mart.) Griseb. (Amaranthaceae) in mice. Pak. J. Pharm. Sci. 25, 583-587.

15. Wu, C., Hsieh, H., Lin, J. and Yen, G. 2013 Alternanthera paronychioides protects pancreatic $\beta$-cells from glucotoxicity by its antioxidant, antiapoptotic and insulin secretagogue actions. Food Chem. 139, 362-370.

16. Majhenič, L., Škerget, M. and Knez, Ž. 2007. Antioxidant and antimicrobial activity of guarana seed extracts. Food Chem.104, 1258-1268. 
17. Uddin, R., Saha, M.R., Subhan, N., Hossain, H., Jahan, I.A., Akter, R. and Alam, A. 2014. HPLC-Analysis of polyphenolic compounds in Gardenia jasminoides and determination of antioxidant activity by using free radical scavenging assays. Adv. Pharm. Bull. 4, 273-281.

18. Alam, M.A., Ghani, A., Subhan, N., Rahman, M.M., Haque, M.S., Majumder, M.M., Akter, R., Nahar, L. and Sarker, S. 2008. Antioxidant and membrane stabilizing properties of the flowering tops of Anthocephalus cadamba. Nat Prod Commun. 3, 65-70.

19. Oyaizu, M. 1986. Studies on product of browning reaction prepared from glucose amine. Jpn. J. Nutr. 44, 307-315.

20. Ruch, R., Cheng, S. and Klaunig, J. 1989. Prevention of cytotoxicity and inhibition of intercellular communication by antioxidant catechins isolated from Chinese green tea. Carcinogenesis. 10, 1003-1008.

21. Niehaus, W.G. and Samuelsson, B. 1968. Formation of malonaldehyde from phospholipid arachidonate during microsomal lipid peroxidation. Eur. J. Biochem. 6, 126-130.

22. Jiang, Z.Y., Hunt, J.V. and Wolff, S.P. 1992. Ferrous ion oxidation in the presence of xylenol orange for detection of lipid hydroperoxide in low density lipoprotein. Analytical Biochem. 202, 384-389.

23. Sinha, A.K. 1972. Colorimetric assay of catalase. Analytical Biochem.47, 389-394.

24. Tracey, W.R., Tse, J. and Carter, G. 1995. Lipopolysaccharide-induced changes in plasma nitrite and nitrate concentrations in rats and mice: pharmacological evaluation of nitric oxide synthase inhibitors. J. Pharmacol. Exp. Ther. 272, 1011-1015.

25. Dai, J. and Mumper, R.J. 2010. Plant phenolics: extraction, analysis and their antioxidant and anticancer properties. Molecules. 15, 7313-7352.

26. Jacobo-Velázquez, D.A. and Cisneros-Zevallos, L. 2009. Correlations of antioxidant activity against phenolic content revisited: A new approach in data analysis for food and medicinal plants. J. Food Sci. 74, R107-R113.

27. Chuanphongpanich, S. and Phanichphant, S. 2006. Method development and determination of phenolic compounds in broccoli seeds samples. Chiang Mai. J. Sci. 33, 103-107.

28. Sakakibara, H., Honda, Y., Nakagawa, S., Ashida, H. and Kanazawa, K. 2003. Simultaneous determination of all polyphenols in vegetables, fruits, and teas. J. Agric. Food Chem. 51, 571.581.

29. Tsao, R. and Yang, R. 2003. Optimization of a new mobile phase to know the complex and real polyphenolic composition: towards a total phenolic index using highperformance liquid chromatography. J. Chromatography. A 1018, 29-40.

30. Cai, Y., Luo, Q., Sun, M. and Corke, H. 2004. Antioxidant activity and phenolic compounds of 112 traditional Chinese medicinal plants associated with anticancer. Life Sci. 74, 2157-2184.
31. Viuda-Martos, M., Ruiz-Navajas, Y., Fernández-López, J., Sendra, E., Sayas-Barberá, E. and Pérez-Álvarez, J.A. 2011. Antioxidant properties of pomegranate (Punica granatum L.) bagasses obtained as co-product in the juice extraction. Food Res. Int. 44, 1217-1223.

32. Venkatesh, S., Madhava, R.B., Dayanand, R.G., Mullangi, R. and Lakshman, M. 2010. Antihyperglycemic and hypolipidemic effects of Helicteres isora roots in alloxaninduced diabetic rats: A possible mechanism of action. $J$. Nat. Med. 64, 295-304.

33. Li, W.L., Zheng, H.C., Bukuru, J. and De Kimpe, N. 2004. Natural medicines used in the traditional Chinese medical system for therapy of diabetes mellitus. J. Ethnopharmacol. 92, 1-21.

34. Celik, S., Erdogan, S. and Tuzcu, M. 2009. Caffeic acid phenethyl ester (CAPE) exhibits significant potential as an antidiabetic and liver-protective agent in streptozotocininduced diabetic rats. Pharmacol. Res. 60, 270-276.

35. Jung, U.J., Lee, M.K., Park, Y.B., Jeon, S.M. and Choi, M.S. 2006. Antihyperglycemic and antioxidant properties of caffeic acid in $\mathrm{db} / \mathrm{db}$ mice. J. Pharmacol. Exp. Ther. 318, 476-483.

36. Vessal, M., Hemmati, M. and Vasei, M. 2003. Antidiabetic effects of quercetin in streptozocin-induced diabetic rats. Comparative Biochemistry and Physiology Part C: Toxicol Pharmacol. 135, 357-364.

37. El-Demerdash, F.M., Yousef, M.I. and El-Naga, N.I. 2005. Biochemical study on the hypoglycemic effects of onion and garlic in alloxan-induced diabetic rats. Food Chem. Toxicol. 43, 57-63.

38. Sasaki, S. and Inoguchi, T. 2012. The role of oxidative stress in the pathogenesis of diabetic vascular complications. Diabetes Metab. J. 36, 255-261.

39. Monnier, L., Mas, E., Ginet, C., Michel, F., Villon, L., Cristol, J.P. and Colette, C. 2006. Activation of oxidative stress by acute glucose fluctuations compared with sustained chronic hyperglycemia in patients with type 2 diabetes. JAMA. 295, 1681-1687.

40. Pitocco, D., Tesauro, M., Alessandro, R., Ghirlanda, G. and Cardillo, C. 2013. Oxidative stress in diabetes: implications for vascular and other complications. Int. J. Mol. Sci. 14, 21525-21550.

41. Robertson, R.P. and Harmon, J.S. 2006. Diabetes, glucose toxicity, and oxidative stress: A case of double jeopardy for the pancreatic islet beta cell. Free Radic. Biol. Med. 41, 177184.

42. Ramar, M., Manikandan, B., Raman, T., Priyadarsini, A., Palanisamy, S., Velayudam, M., Munusamy, A., Marimuthu, P.N. and Vaseeharan, B. 2012. Protective effect of ferulic acid and resveratrol against alloxan-induced diabetes in mice. Eur. J. Pharmacol. 690, 226-235. 